\title{
Paenibacillus humicus sp. nov., isolated from poultry litter compost
}

\author{
Ivone Vaz-Moreira, ${ }^{1}$ Cátia Faria, ${ }^{1}$ M. Fernanda Nobre, ${ }^{2}$ Peter Schumann, ${ }^{3}$ \\ Olga C. Nunes ${ }^{4}$ and Célia M. Manaia ${ }^{1}$
}

Correspondence

Célia M. Manaia

cmmanaia@esb.ucp.pt

\author{
${ }^{1}$ Escola Superior de Biotecnologia, Universidade Católica Portuguesa, 4200-072 Porto, Portugal \\ ${ }^{2}$ Departamento de Zoologia, Universidade de Coimbra, 3004-517 Coimbra, Portugal \\ ${ }^{3} \mathrm{DSMZ}$ - Deutsche Sammlung von Mikroorganismen und Zellkulturen GmbH, Inhoffenstraße 7b, \\ D-38124 Braunschweig, Germany \\ ${ }^{4}$ LEPAE - Departamento de Engenharia Química, Faculdade de Engenharia, Universidade do Porto, \\ 4200-465 Porto, Portugal
}

\begin{abstract}
Two bacterial strains, $\mathrm{PC}-142$ and $\mathrm{PC}-147^{\top}$, isolated from poultry litter compost, were characterized with respect to their phenetic and phylogenetic characteristics. The isolates were endospore-forming rods that were reddish in colour after Gram staining. They were catalaseand oxidase-positive, were able to degrade starch and gelatin and grew at $15-40{ }^{\circ} \mathrm{C}$ and $\mathrm{pH}$ 5.5-10.0. The predominant fatty acids were anteiso- $C_{15: 0}$, iso- $C_{15: 0}$ and iso- $C_{16: 0}$, the major respiratory quinone was menaquinone MK-7, the cell-wall peptidoglycan was of the $A 1 \gamma$ type and the $\mathrm{G}+\mathrm{C}$ content of the DNA was $58 \mathrm{~mol} \%$. The $16 \mathrm{~S}$ rRNA gene sequence analysis and phenetic characterization indicated that these organisms belong to the genus Paenibacillus, with Paenibacillus pasadenensis SAFN-007 ${ }^{\top}$ as the closest phylogenetic neighbour (97.5\%). Strains PC-142, PC-147 ${ }^{\top}$ and $P$. pasadenensis SAFN-007 ${ }^{\top}$ represent a novel lineage within the genus Paenibacillus, characterized by a high DNA G $+\mathrm{C}$ content (58-63 mol\%). The low levels of 16S rRNA gene sequence similarity with respect to other taxa with validly published names and the identification of distinctive phenetic features in the two isolates indicate that strains PC-142 and PC-147 ${ }^{\top}$ represent a novel species of the genus Paenibacillus, for which the name Paenibacillus humicus sp. nov. is proposed. The type strain is PC-147 ${ }^{\top}$ (=DSM

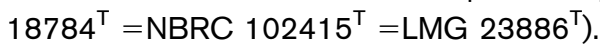

In a study designed to characterize culturable heterotrophic bacteria in composts, endospore-forming rods affiliated to the genus Paenibacillus were isolated from poultry litter compost. This compost was produced from chicken wastes from aviaries, meat meal, bird bones, vegetable ash and grape husks. The material was stored for 5-6 months until it had composted. The composting process was conducted in piles, under a covered area, for a period of 45 days. Two isolates from the compost had a randomly amplified polymorphic DNA (RAPD) profile that was distinct from those of other bacterial isolates (identified as members of the genera Staphylococcus, Bacillus and Pseudomonas; data not shown) recovered from the same compost. On the basis of 16S rRNA gene sequence analysis, the two isolates,

The GenBank/EMBL/DDBJ accession numbers for the 16S rRNA gene sequences of strains PC-142 and PC- $147^{\top}$ are AM411529 and AM411528, respectively.

RAPD patterns and an extended phylogenetic tree for strains PC-142 and $\mathrm{PC}-147^{\top}$ and related taxa are available as supplementary figures with the online version of this paper. designated strains PC-142 and PC- $147^{\mathrm{T}}$, were presumed to be members of the genus Paenibacillus and were further characterized by using a polyphasic approach.

The bacterial isolates were recovered on plate count agar (PCA) at $30{ }^{\circ} \mathrm{C}$, purified by subculturing on the same medium and then cryopreserved at $-80{ }^{\circ} \mathrm{C}$ in a nutritive broth supplemented with $15 \%(\mathrm{v} / \mathrm{v})$ glycerol. PCA was used for culture maintenance, and biochemical and physiological tests were performed in modified Luria-Bertani medium (Tiago et al., 2004) incubated at $30{ }^{\circ} \mathrm{C}$. Colony and cell morphology, Gram-staining, cytochrome $c$ oxidase and catalase activities, motility and flagellation were assessed according to the methodologies of Murray et al. (1994) and Smibert \& Krieg (1994). The pH range for growth was examined in culture medium containing $12 \mathrm{mM}$ MES (Sigma), to adjust the $\mathrm{pH}$ to 5.5, and $12 \mathrm{mM}$ CAPS (Sigma), to adjust the $\mathrm{pH}$ to 9.0 and 10.0 . The $\mathrm{NaCl}$ tolerance and temperature ranges for growth were assayed, respectively, in culture medium supplemented with 1,3 and $5 \% \mathrm{NaCl}(\mathrm{w} / \mathrm{v})$ or at $15,36,40$ and 
Table 1. Distinctive characteristics of strains $P C-142$ and $P C-147^{\top}$ and $P$. pasadenensis NBRC $101214^{\top}$

Strains PC-142, PC- $147^{\mathrm{T}}$ and P. pasadenensis NBRC $101214^{\mathrm{T}}$ tested positive for $\beta$-galactosidase, for the hydrolysis of gelatin and aesculin and for the assimilation of the following carbon sources: D-glucose, D-mannitol, $N$-acetylglucosamine, maltose, potassium gluconate, D-xylose, methyl $\beta$-D-xylopyranoside, D-galactose, D-fructose, methyl $\alpha$-D-glucopyranoside, amygdalin, arbutin, salicin, D-cellobiose, D-lactose, D-melibiose, sucrose, trehalose, D-melezitose, D-raffinose, starch, glycogen, gentiobiose and D-turanose. All of the strains tested negative for the following: Gram staining, nitrate reduction, arginine dihydrolase, urease, indole production and glucose fermentation. All were unable to assimilate the following carbon sources: caprate, adipate, malate, citrate, phenylacetate, erythritol, D-arabinose, D-ribose, L-xylose, D-adonitol, L-sorbose, dulcitol, inositol, D-sorbitol, methyl $\alpha$-D-mannopyranoside, inulin, xylitol, D-lyxose, D-tagatose, D-fucose, L-fucose, D-arabitol, L-arabitol, 2-ketogluconate and 5-ketogluconate. Strains PC-142 and PC-147 were negative for anaerobic growth, lysine and ornithine decarboxylase and tryptophan deaminase activities, citrate utilization and $\mathrm{H}_{2} \mathrm{~S}$ production and for growth at $45{ }^{\circ} \mathrm{C}$, with $5 \% \mathrm{NaCl}$ and on Bacillus cereus medium (P. pasadenensis NBRC $101214^{\mathrm{T}}$ not tested). PC-142 and $\mathrm{PC}-147^{\mathrm{T}}$ were unable to use the following carbon sources: (fermentation/oxidation) D-mannitol, inositol, D-sorbitol, L-rhamnose, sucrose, D-melibiose, amygdalin and L-arabinose; (acid production) D-glucose, D-mannitol, inositol, D-sorbitol, L-rhamnose, L-arabinose, D-arabinose, glycerol, erythritol, D-ribose, D-xylose, L-xylose, D-adonitol, methyl $\beta$-D-xylopyranoside, D-galactose, D-mannose, L-sorbose, dulcitol, methyl $\alpha$-D-mannopyranoside, methyl $\alpha$-D-glucopyranoside, $N$-acetylglucosamine, arbutin, inulin, D-melezitose, D-raffinose, starch, glycogen, xylitol, gentiobiose, D-lyxose, D-tagatose, D-fucose, L-fucose, D-arabitol, L-arabitol, potassium gluconate, 2-ketogluconate and 5ketogluconate (data not shown for P. pasadenensis NBRC $101214^{\mathrm{T}}$ ). Strain PC-142 showed weak acid production for D-lactose, D-melibiose and D-turanose; strain PC- $147^{\mathrm{T}}$ was unable to produce acids from these carbon sources (data not shown for P. pasadenensis NBRC 101214 ${ }^{\mathrm{T}}$ ).

\begin{tabular}{|lcc|}
\hline Characteristic & Strains PC-142 and PC-147 & P. pasadenensis NBRC 101214 \\
\hline Growth with $3 \% \mathrm{NaCl}$ & - \\
Assimilation of: & + & + \\
L-Arabinose & & + \\
Glycerol & - & + \\
Malate & - & + \\
L-Rhamnose & - & \\
Acid production from: & & + \\
L-Arabinose & - & + \\
D-Fructose & - & + \\
D-Galactose & - & + \\
D-Glucose & - & + \\
Glycogen & - & + \\
D-Mannose & - & + \\
D-Mannitol & - & + \\
D-Melezitose & - & + \\
D-Raffinose & - & + \\
Starch & - & + \\
D-Xylose & - & Floor of clean-room entrance \\
DNA G + C content $($ mol\%) & 58 & \\
Isolation source & Poultry litter compost & + \\
& & \\
\hline
\end{tabular}

$45{ }^{\circ} \mathrm{C}$. The ability of the strains to grow in the presence of $0.001 \%(\mathrm{w} / \mathrm{v})$ lysozyme was tested in tryptic casein soy broth medium. Anaerobic growth was tested under a $\mathrm{N}_{2}$ saturated atmosphere in the presence of $0.1 \% \mathrm{KNO}_{3}$ $(\mathrm{w} / \mathrm{v})$. The same medium, under aerobic conditions, was used to assay nitrate reduction. The production of extracellular amylases, gelatinases and tweenases (Tween 80) was tested as described previously (Tiago et al., 2004). Other biochemical tests were performed using API $20 \mathrm{E}$ and API 20NE galleries, and the nutritional pattern was determined using API $50 \mathrm{CH}$ and API 20NE kits, according to the instructions of the manufacturer (bioMérieux) at $30{ }^{\circ} \mathrm{C}$. The API $50 \mathrm{CH}$ carbon-source utilization kit was used both with the medium recommended for testing acid production (50 $\mathrm{CHB} / \mathrm{E}$; bioMérieux) and with mineral medium B (Barreiros et al., 2003) supplemented with $4 \mathrm{mM}\left(\mathrm{NH}_{4}\right)_{2} \mathrm{SO}_{4}$, vitamins ( $p$-aminobenzoic acid, folic acid, nicotinic acid, pantothenic acid, biotin, cyanocobalamin, inositol, riboflavin, pyridoxine, thiamine) (40 $\mathrm{g} \mathrm{l}^{-1}$ ) and nitrogenated bases (adenine, cytosine, 


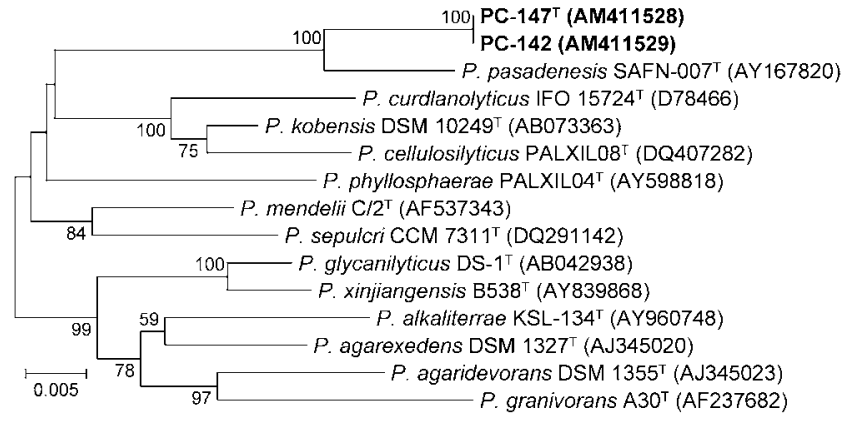

Fig. 1. Neighbour-joining phylogenetic tree, based on $16 \mathrm{~S}$ rRNA gene sequences, showing the nearest neighbours of strain PC142 and $\mathrm{PC}-147^{\top}$. Bootstrap percentages were generated from 1000 resamplings; only values greater than $50 \%$ are shown. Bar, 1 substitution per 200 nucleotide positions. An extended version of this tree is available as Supplementary Fig. S2 in IJSEM Online.

inosine, thymine and uracil) and amino acids (methionine, phenylalanine, tryptophan, arginine, histidine, alanine, glycine, proline and tyrosine) $\left(5 \mathrm{mg}^{-1}\right)$.

The DNA G $+\mathrm{C}$ content, respiratory quinones and fatty acid methyl ester composition were determined as described previously (Vaz-Moreira et al., 2007) using the methods of Mesbah et al. (1989), Tindall (1989) and Kuykendall et al. (1988), respectively. The diaminopimelic acid isomer was determined by one-dimensional TLC on cellulose plates (Merck) by using the solvent system of Rhuland et al. (1955).

The sequence of the 16S rRNA gene was determined after PCR amplification of total DNA extracts as described previously (Rainey et al., 1996). The 16S rRNA gene sequence was compared with others available in the GenBank/EMBL/DDBJ database by using BLASTN (NCBI) and FASTA (EMBL-EBI) and was aligned with reference sequences. Phylogenetic analysis was conducted using MEGA, version 3.1 (Kumar et al., 2004). Levels of sequence relatedness were estimated using the model of Jukes \& Cantor (1969), and the phylogenetic tree was created using the neighbour-joining method. Other methods (minimum evolution and maximum parsimony) were used to assess the tree stability. A total of 1322 nucleotide positions in each $16 \mathrm{~S}$ rRNA gene were included in the analysis. Nonhomologous and ambiguous nucleotide positions were excluded from the calculations.

After $24 \mathrm{~h}$ incubation at $30{ }^{\circ} \mathrm{C}$ on PCA, isolates PC-142 and $\mathrm{PC}-147^{\mathrm{T}}$ formed flat, very smooth, translucent colonies that tended to produce a swarming effect. These strains were unable to produce growth on Bacillus cereus medium (Pronadisa) agar after 7 days incubation. They were able to produce acid from, and assimilate, several sugars (see Table 1 and the species description). The major fatty acid methyl esters were anteiso- $\mathrm{C}_{15: 0}$, iso- $\mathrm{C}_{15: 0}$ and iso- $\mathrm{C}_{16: 0}$, which accounted for more than $60 \%$ of the total.
Table 2. Fatty acid methyl ester compositions of strains PC-142 and PC-147 and P. pasadenensis NBRC $101214^{\top}$

\begin{tabular}{|lccc|}
\hline $\begin{array}{l}\text { Fatty acid methyl } \\
\text { ester }\end{array}$ & PC-142 & PC-147 $^{\mathbf{T}}$ & $\begin{array}{l}\text { P. pasadenensis } \\
\text { NBRC 101214 }\end{array}$ \\
\hline iso- $\mathrm{C}_{14: 0}$ & 1.7 & 1.5 & 1.2 \\
$\mathrm{C}_{14: 0}$ & 1.2 & 1.5 & - \\
${\text { iso- } \mathrm{C}_{15: 0}}_{\text {anteiso-C }_{15: 0}}^{21.1}$ & 16.9 & 16.4 \\
$\mathrm{C}_{15: 0}$ & 39.2 & 41.9 & 38.2 \\
iso- $_{16: 0}$ & 2.6 & 1.6 & 4.1 \\
$\mathrm{C}_{16: 0}$ & 13.2 & 10.6 & 12.3 \\
$\mathrm{C}_{16: 1}$ & 6.8 & 8.0 & 5.1 \\
iso-C $_{17: 0}$ & - & - & 3.3 \\
anteiso-C $_{17: 0}$ & 5.8 & 4.4 & 7.3 \\
$\mathrm{C}_{18: 0}$ & 5.7 & 6.1 & 8.3 \\
Others $^{*}$ & 1.4 & 1.6 & - \\
& 1.4 & 5.9 & 3.9 \\
\hline
\end{tabular}

${ }^{*}$ Includes anteiso- $\mathrm{C}_{13: 0}$, anteiso- $\mathrm{C}_{14: 0}, \mathrm{C}_{16: 1} \omega 7 c$ alcohol, anteiso$\mathrm{C}_{17: 1} \omega 9 c, \mathrm{C}_{18: 1} \omega 9 c$ and summed feature 10 (unidentified).

Other minor components (representing more than 4\%) were iso- $\mathrm{C}_{17: 0}$, anteiso- $\mathrm{C}_{17: 0}$ and $\mathrm{C}_{16: 0}$. The DNA G+C content for PC- $147^{\mathrm{T}}$ and PC-142 was, respectively, $58.3 \pm$ 0.3 and $58.1 \pm 0.2 \mathrm{~mol} \%$. Menaquinone MK-7 was the major respiratory quinone in both strains. The diagnostic diamino acid of the peptidoglycan was meso-diaminopimelic acid, suggesting the presence of peptidoglycan type A $1 \gamma$ (Schleifer \& Kandler, 1972). Strains PC-142 and PC$147^{\mathrm{T}}$ differed only in the ability to produce acid from three carbon sources (D-lactose, D-melibiose and D-turanose); they had similar fatty acid methyl ester compositions and DNA G $+\mathrm{C}$ contents and their $16 \mathrm{~S}$ rRNA gene sequences were identical. These findings were confirmed by the similarity of the RAPD patterns obtained for isolates PC142 and PC- $147^{\mathrm{T}}$ (see Supplementary Fig. S1, available in IJSEM Online).

The diagnostic diamino acid of the peptidoglycan, the menaquinone and the fatty acid methyl ester composition of isolates PC-142 and PC- $147^{\mathrm{T}}$ confirm the results of the $16 \mathrm{~S}$ rRNA gene sequence comparative analysis, identifying these organisms as members of the genus Paenibacillus. On the basis of the 16S rRNA gene sequence analysis, the closest phylogenetic neighbours of isolates PC-142 and PC$147^{\mathrm{T}}$ are Paenibacillus pasadenensis SAFN-007 ${ }^{\mathrm{T}}$ (97.5\%), Paenibacillus kobensis DSM $10249^{\mathrm{T}}(94.3 \%)$ and Paenibacillus mendelli $\mathrm{C} / 2^{\mathrm{T}}$ (93.8\%) (Fig. 1; an extended version of this tree is available as Supplementary Fig. S2). In the light of these results, the nutritional and chemotaxonomic properties of strains PC-142 and PC- $147^{\mathrm{T}}$ were compared with those of $P$. pasadenensis NBRC $101214^{\mathrm{T}}$ (Osman et al., 2006) (Tables 1 and 2). The fatty acid methyl ester patterns obtained for PC-142, PC- $147^{\mathrm{T}}$ and P. pasadenensis NBRC $101214^{\mathrm{T}}$ confirm the taxonomic relatedness of these organisms and their affiliation to the same genus (Table 2). However, the DNA G+C contents of these 
three organisms $\left(58.3 \pm 0.3 \mathrm{~mol} \%\right.$ for PC- $147^{\mathrm{T}}, 58.1 \pm$ $0.2 \mathrm{~mol} \%$ for PC- 142 and $63.4 \pm 0.6 \mathrm{~mol} \%$ for P. pasadenensis NBRC $101214^{\mathrm{T}}$ ) demonstrate the taxonomic distinctiveness of the two isolates. Amongst the highest DNA $\mathrm{G}+\mathrm{C}$ contents reported for this genus were those obtained for Paenibacillus validus (54-55 mol\%; buoyant density method) (Heyndrickx et al., 1995) and Paenibacillus panacisoli (Ten et al., 2006). Strains PC-142 and PC- $147^{\mathrm{T}}$ and $P$. pasadenensis NBRC $101214^{\mathrm{T}}$ form a high-G $+\mathrm{C}$ lineage within the genus Paenibacillus.

As strains PC-142 and PC- $147^{\mathrm{T}}$ show less than $98.5 \% 16 \mathrm{~S}$ rRNA gene sequence similarity with respect to their closest phylogenetic neighbour, $P$. pasadenensis, DNA-DNA hybridizations to demonstrate their separate species status were considered unnecessary in view of the results of recent investigations (Stackebrandt \& Ebers, 2006). Characteristics that serve to distinguish PC-142 and PC- $147^{\mathrm{T}}$ from their closest phylogenetic neighbour, $P$. pasadenensis NBRC $101214^{\mathrm{T}}$, are presented in Table 1 . On the basis of the data presented, strains PC-142 and PC- $147^{\mathrm{T}}$ represent a novel species of the genus Paenibacillus, for which the name Paenibacillus humicus sp. nov. is proposed.

\section{Description of Paenibacillus humicus sp. nov.}

Paenibacillus humicus (hu'mi.cus, L. n. humus earth, soil and, in earth sciences or agriculture, humus; L. suff. -icus - $a$ -um suffix used with the sense of belonging to; N.L. masc. adj. humicus pertaining to humus).

Cells are motile rods $(2.0 \mu \mathrm{m}$ long and $0.5 \mu \mathrm{m}$ wide) with peritrichous flagella. Gram staining is negative. Terminal, ellipsoidal endospores are produced in swollen sporangia. On nutritive medium, such as PCA or Luria-Bertani agar, colonies are white/translucent, very smooth and flat. Swarming is observed. Catalase- and oxidase-positive. Growth occurs in the presence of $3 \% \mathrm{NaCl}$ and at 15 $40{ }^{\circ} \mathrm{C}$ and $\mathrm{pH}$ 5.5-10. No growth occurs under anaerobic conditions, at $45{ }^{\circ} \mathrm{C}$ or in the presence of $5 \% \mathrm{NaCl}$. Nitrate is not reduced. Tests positively for $\beta$-galactosidase, VogesProskauer (API 20NE) and growth in the presence of $0.001 \%$ lysozyme. Starch, gelatin, Tween 80 and aesculin are hydrolysed. The following carbon sources are assimilated: starch, amygdalin, arbutin, D-cellobiose, D-fructose, D-galactose, gentiobiose, D-glucose, glycogen, D-lactose, maltose, D-mannitol, D-melezitose, D-melibiose, methyl $\alpha$ D-glucopyranoside, methyl $\beta$-D-xylopyranoside, $N$-acetylglucosamine, potassium gluconate, D-raffinose, salicin, sucrose, trehalose, D-turanose and D-xylose. Acid is produced from amygdalin, D-cellobiose, maltose, sucrose and trehalose. The peptidoglycan cell wall is of the A1 $\gamma$ type. The major cellular fatty acid components are anteiso$\mathrm{C}_{15: 0}$ (approx. $\left.40 \%\right)$, iso- $\mathrm{C}_{15: 0}(17-21 \%)$ and iso- $\mathrm{C}_{16: 0}$ $(11-13 \%)$. The major respiratory quinone is MK-7 and the DNA G + C content is $58 \mathrm{~mol} \%$.

The type strain, PC $-147^{\mathrm{T}}\left(=\mathrm{DSM} 18784^{\mathrm{T}}=\mathrm{NBRC} 102415^{\mathrm{T}}\right.$ $=\mathrm{LMG} 23886^{\mathrm{T}}$ ), was isolated from final compost produced from poultry litter.

\section{Acknowledgements}

The authors acknowledge Luisa Barreiros (Faculdade de Engenharia da Universidade do Porto) for her helpful collaboration, Elisabete Silva (Escola Superior de Tecnologia de Viseu, Instituto Politécnico de Viseu) for providing the poultry litter compost and Milton S. da Costa (Departamento de Bioquímica da Universidade de Coimbra) for help with the fatty acid methyl ester analyses.

\section{References}

Barreiros, L., Nogales, B., Manaia, C. M., Ferreira, A. C. S., Pieper, D. H., Reis, M. A. \& Nunes, O. C. (2003). A novel pathway for mineralization of the thiocarbamate herbicide molinate by a defined bacterial mixed culture. Environ Microbiol 5, 944-953.

Heyndrickx, M., Vandemeulebroecke, K., Scheldeman, P., Hoste, B., Kersters, K., De Vos, P., Logan, N. A., Aziz, A. M., Ali, N. \& Berkeley, R. C. W. (1995). Paenibacillus (formerly Bacillus) gordonae (Pichinoty et al. 1986) Ash et al. 1994 is a later subjective synonym of Paenibacillus (formerly Bacillus) validus (Nakamura 1984) Ash et al. 1994: emended description of P. validus. Int J Syst Bacteriol 45, 661-669.

Jukes, T. H. \& Cantor, C. R. (1969). Evolution of protein molecules. In Mammalian Protein Metabolism, vol. 3, pp. 21-132. Edited by H. N. Munro. New York: Academic Press.

Kumar, S., Tamura, K. \& Nei, M. (2004). MEGA3: integrated software for molecular evolutionary genetics analysis and sequence alignment. Brief Bioinform 5, 150-163.

Kuykendall, L. D., Roy, M. A., O’Neill, J. J. \& Devine, T. E. (1988). Fatty acids, antibiotic resistance, and deoxyribonucleic acid homology groups of Bradyrhizobium japonicum. Int J Syst Bacteriol 38, 358-361.

Mesbah, M., Premachandran, U. \& Whitman, W. B. (1989). Precise measurement of the $\mathrm{G}+\mathrm{C}$ content of deoxyribonucleic acid by high-performance liquid chromatography. Int J Syst Bacteriol 39, 159-167.

Murray, R. G. E., Doetsch, R. N. \& Robinow, F. (1994). Determinative and cytological light microscopy. In Methods for General and Molecular Bacteriology, pp. 21-41. Edited by P. Gerhardt, R. G. E. Murray, W. A. Wood \& N. R. Krieg. Washington, DC: American Society for Microbiology.

Osman, S., Satomi, M. \& Venkateswaran, K. (2006). Paenibacillus pasadenensis sp. nov. and Paenibacillus barengoltzii sp. nov., isolated from a spacecraft assembly facility. Int J Syst Evol Microbiol 56, 1509-1514.

Rainey, F. A., Ward-Rainey, N., Kroppenstedt, R. M. \& Stackebrandt, E. (1996). The genus Nocardiopsis represents a phylogenetically coherent taxon and a distinct actinomycete lineage: proposal of Nocardiopsaceae fam. nov. Int J Syst Bacteriol 46, 1088-1092.

Rhuland, L. E., Work, E., Denman, R. F. \& Hoare, D. S. (1955). The behavior of the isomers of $\alpha, \varepsilon$-diaminopimelic acid on paper chromatograms. J Am Chem Soc 77, 4844-4846.

Schleifer, K. H. \& Kandler, O. (1972). Peptidoglycan types of bacterial cell walls and their taxonomic implications. Bacteriol Rev 36, 407-477.

Smibert, R. M. \& Krieg, N. R. (1994). Phenotypic characterization. In Methods for General and Molecular Bacteriology, pp. 607-654. Edited by P. Gerhardt, R. G. E. Murray, W. A. Wood \& N. R. Krieg. Washington, DC: American Society for Microbiology.

Stackebrandt, E. \& Ebers, J. (2006). Taxonomic parameters revisited: tarnished gold standards. Microbiol Today 33, 152-155.

Ten, L. N., Baek, S.-H., Im, W.-T., Lee, M., Oh, H. W. \& Lee, S.-T. (2006). Paenibacillus panacisoli sp. nov., a xylanolytic bacterium 
isolated from soil in a ginseng field in South Korea. Int J Syst Evol Microbiol 56, 2677-2681.

Tiago, I., Teixeira, I., Silva, S., Chung, P., Veríssimo, A. \& Manaia,

C. M. (2004). Metabolic and genetic diversity of mesophilic and thermophilic bacteria isolated from composted municipal sludge on

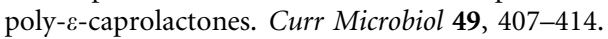

Tindall, B. J. (1989). Fully saturated menaquinones in the archaebacterium Pyrobaculum islandicum. FEMS Microbiol Lett 60, 251-254.

Vaz-Moreira, I., Nobre, M. F., Nunes, O. C. \& Manaia, C. M. (2007). Gulbenkiania mobilis gen. nov., sp. nov., isolated from treated municipal wastewater. Int J Syst Evol Microbiol 57, 1108-1112. 